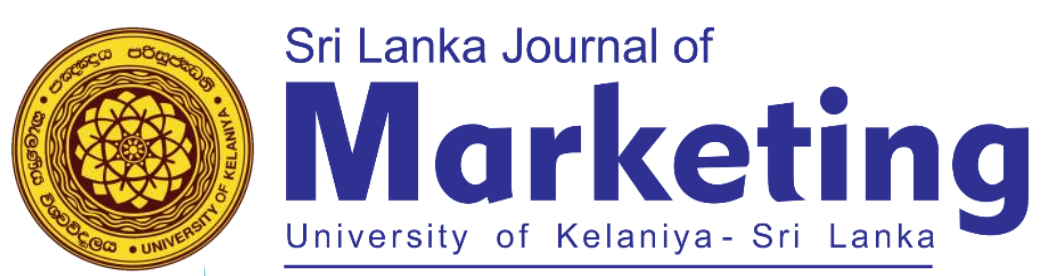

\title{
Measuring Customer Intrinsic Value, Brand Trust and Consumer- Brand Relationship in the Life Insurance Industry: Scale Development and Validation
}

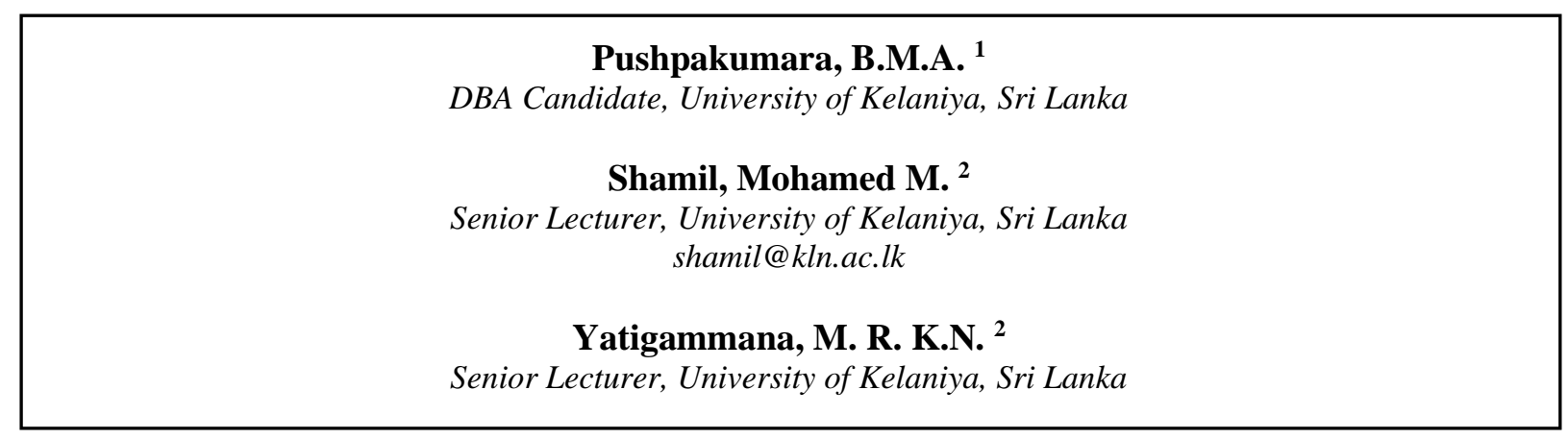

\section{ABSTRACT}

This is the first study to comprehensively explore, develop and validate a scale for customer intrinsic value, brand trust and consumer-brand relationship behavior for the life insurance industry in Sri Lanka. This task was realized through an extensive literature review and discussions with academic experts and practitioners in the insurance field. A factor analysis was performed using the principal component analysis with Varimax rotation. The refined scales exhibit reliability, convergent validity, discriminant validity and will be useful for future researchers and managers.

Keywords: Altruistic Values, Brand Trust, Consumer-Brand Relationship, Factor Analysis, Hedonic Values 


\section{INTRODUCTION}

Research in the areas of consumer satisfaction and thoughts, consumer interactions with a brand, and consumer-brand relationship behavior have emerged as new fields of study (MacInnis and Folkes, 2017; Keller, 2012). Consumer-brand relationship behavior has been identified as an important research area in marketing (Keller 2012), and it has been claimed that customer intrinsic value is highly important to study consumer behavior under consumer-brand relationship (Gallarza et al., 2017). Consumption experience is realized through a self-justifying end in the form of intrinsic value. A person with the intrinsic value is mostly concerned about himself to a certain extent, and the intrinsic value is formed self orientally (self-oriented) and other orientally (other-oriented). The concept of self-oriented is directly related to hedonic value and while the concept of other-oriented is related to altruistic value (Holbrook, 2006) and these values are considered to be the branches of intrinsic value (Gallarza et al., 2016). Schema theory, a theoretical framework found in branding related research (Kim et al. 2019; Davvetas and Diamantopoulos, 2018) has been suggested to be considered for systematically reviewing the customer-brand relationship behaviour (Halkias, 2015). Persuasive communication theory and commitment trust theory have been used as a supportive theory to review the customer-brand relationship behaviour (Morgan and Hunt, 1994; Desai and Raju, 2007; Hess and Story, 2005; Louis and Lombart, 2010). Grounded on the above theories, the purpose of this study is to develop a scale for altruistic value, hedonic value, brand trust and consumer-brand relationship behaviour for the life insurance industry in Sri Lanka.

Review of past studies that discusses customer intrinsic values, brand trust and consumer-brand relationship reveals that many studies have paid attention to the banking industry and neglected equally important other financial services sectors (Robson, 2015). Accordingly, this study intends to fill this gap and address this imbalance by exploring the above-mentioned constructs and developing a scale that may be relevant to the life insurance industry. Within the financial services industry, the life insurance industry has been singled out as a sector worthy of further research. Delport et al., (2011) state that the value of customer relationships is of particular importance in services like life insurance. There have been few studies that attempted to develop scales and measure constructs in the fields of consumer behaviour and marketing that focuses on the financial services industry. Most studies about the consumer-brand relationship have emerged from the developed markets, and there have been calls to explore the consumer-brand relationship in developing market contexts (Ghani and Tuhin, 2018). Therefore, this study is of significance to a country like Sri Lanka, classified as a developing country in the world. Sheth and Parvatiyar (1995) contend that there is a lack of understanding of consumerbrand relationships in underdeveloped consumer services markets. Moreover, Tiefenbacher and Olbrich (2015) emphasize that customer perceived value and value creation has been understudied in the life insurance industry, and the attention on consumer values in the life insurance industry has increased. 
The choice of Sri Lanka for this study is motivated by several factors. Firstly, Sri Lanka is a middleincome country as per the United Nations Report in 2017. Secondly, increasing life insurance penetration has been and continues to be one of the biggest challenges for Sri Lanka. Long term insurance penetration in Sri Lanka in 2016 stood at 0.54\% and was 0.49\% in 2015 (IBSL 2016). Expansion of the insurance sector in Sri Lanka has been slow, although there is a marginal improvement in life insurance penetration. Thirdly, the insurance sector in Sri Lanka is one of the significant contexts that demand empirical studies (Gunawardane et al., 2016). Fourthly, the growing elderly population may be of importance to the life insurance service providers in Sri Lanka. The percentage of the aged population (above 60 years) was $9.8 \%$ in 2000. Aged population in Sri Lanka, would be above 21.2\% by the year 2030 and Sri Lanka will be the country with the highest percentage of aged population among other south and central Asian countries (United Nation, 2017). The ageing population of a country can be viewed as an asset rather than a social burden, and it may create successful and innovative business opportunities in commercial businesses such as life insurance. The growth prospect of life insurance in Sri Lanka also suggest the need for research that focuses on developing scales and measuring constructs. This study, therefore, is expected to contribute knowledge for future researchers and their studies.

\section{REVIEW OF RELEVANT LITERATURE}

Schema theory provides a comprehensive framework to analyze how customers perceive brand information (Halkias, 2015). The theory specifies that consumers obtain knowledge by analyzing information. The internal structure of schemata highly influences the brand, and it allows us to investigate brand-specific knowledge (Halkias and Kokkinaki, 2017). The created schemata are useful to evaluate the latest information relevant to the new brand (Lurigio and Carroll, 1985). Several prior studies have emphasized the importance of Schema theory to review consumer-brand relationship behaviour (Davvetas and Halkias, 2019; Halkias and Kokkinaki, 2017; Davvetas and Diamantopoulos, 2016; Halkias, 2015). The number of academic journal articles dealing with research on consumerbrand relationships has rapidly increased, and they reflect the relevance of this research area (Fetscherin and Heinrich, 2015). Constructs have also been developed using the persuasive communication theory and commitment trust theory (Morgan and Hunt, 1994; Desai and Raju, 2007; Hess and Story, 2005; Louis and Lombart, 2010). Persuasive communication involves the use of verbal messages to influence attitude and behaviour. Although the context of persuasion must be considered, the verbal messagedesigned to sway the hearts and minds of the receivers - is at the core of persuasive communication. Persuasive communication is required to move people to change their behaviour as desired by the communicator.

Customer value has been explained from various viewpoints, namely interactive, relativistic, preference and experience. Customer value has been entailed as an interaction between some subject (a consumer) 
and some object (a product) according to the interaction perspective. This interactionist position maintains that value depends on some physical or mental object (Frondizi, 1971). The relativistic position views value as situational in that it depends on the context in which the evaluative judgment occurs. Customer value is comparative among objects, across people and situations (Morris, 1996). Consumer researchers have found various names by which to refer to the general concept of an evaluative judgment like positive-negative, favourable-unfavourable, pro-con, approach-avoidance, plus-minus, good-bad or liking-disliking depending on customer preference. Finally, based on the available evidence, it can be stated that customer value resides not in the purchase but rather in the consumption experience(s) derived (Hirschman and Holbrook, 1982). One type of value that can be understood by comparing it with other types of value to which it is closely related. Consumer values have influenced consumer purchase decisions.

Schwatz (1994) plotted human values in a two-dimensional space. In this way, the values reflecting openness to change versus conservatism, reflecting whether individuals are open to new things and ideas were plotted against the consumer preference on tradition and conformity. Then, selfenhancement values reflect a concern with one's interests, versus self-transcendence values, reflecting a concern with collective interests (Schwartz, 1994). Consumer's value from the consumption itself is called intrinsic value. These intrinsic dimensions are less studied in perceived value works, and authors have studied by including more extrinsic value dimensions than intrinsic value dimensions (Gallarza et al., 2016). In accordance with Holbrook's classification, functional and social dimensions were included within the extrinsic and altruistic values, whereas hedonic values were included within the intrinsic value. Intrinsic value had been divided into two like self-oriented and other-oriented value (Holbrook, 1999). Intrinsic value is formed by other-oriented and self-oriented, the altruistic value related to otheroriented and self-oriented connected with hedonic value (Holbrook, 2006). Self-oriented value (hedonic value) is for the person's own sake, whereas other-oriented (altruistic value) is value for their sake, beyond the self (Gallarza et al., 2016).

Researchers have acknowledged the significance of hedonic consumption and stressed that effective motives and hedonic aspects play a key role in consumption behaviour (Hirschman and Holbrook, 1982). Hedonic value is better than utilitarian value experience-oriented work such as risk management and insurance-related work (Blinda et al., 2019). Hedonic values appeared to be positively related to the intention of buying (Steg et al., 2014). Altruistic value has been discussed on the importance of the customer's perception of values ranging from customer care, environment to unconditional concern for the welfare of others (Rahmawati, 2018). Intrinsic categories of altruistic value reflect consumer value in a service context (Sanchez et al. 2009). Altruistic attribution has become the determining factor for consumers' trust towards the brand (Rahmawati, 2018). Brand trust has been explained as the willingness of the average consumer to rely on the ability of the brand to perform its stated function 
(Chaudhuri and Holbrook, 2002). Marketing from transaction to relationship could be used to develop a competitive advantage in the life insurance sector (Sekhon and Kennington, 2001). Interrelationship with the brand is secured by brand trust, and it is dependent on the perception with the brand. Consumers' attitudes and brand-related behaviours were being influenced by the brand trust (Delgado et al., 2003; Arnott et al., 2007). The presence of relationship commitment and trust is central to successful relationship marketing (Morgan and Hunt, 1994). The commitment-trust theory of relationship marketing says that two primary factors, trust and commitment, must exist for a relationship to be successful (Morgan and Hunt 1994). Brand trust is a branding concept which has investigated in association with the consumer-brand relationship behaviour (Oliver, 1999). A brand may become an active relationship partner for the consumer and provide meanings in a psycho-socio-cultural context, and it is called the consumer-brand relationship (Fournier, 1998). In most recently extended Fournier's definition of brand relationship, the dimension of organizational and internal culture has been incorporated and aligned in terms of relationship principles (Blackston and Lebar, 2015). Recently, there has been increased attention on explicating the nature, intense and extreme consequences of consumer-brand relationships.

\section{METHODOLOGY FOR SCALE DEVELOPMENT}

Several rigorous stages of scale development were followed to develop reliable and valid items to measure the constructs altruistic value, hedonic value, brand trust and consumer-brand relationship behavior.

\subsection{Respondents and Procedure}

A key aspect of this study to identify respondents that are knowledgeable about their life insurance policy and corporate insurance brand. Statistical review of the Insurance Board of Sri Lanka found 11.13 per cent of the population had taken up a life insurance policy. The current population of Sri Lanka is $21,420,404$ as of July 30, 2020, based on the latest United Nations estimates. Among them, the total number of life insurance policyholders can be identified as 2.38 million (IBSL, 2016). The complete list of all the subjects in the target population cannot be obtained; therefore, the study has utilized a non-probability sample (Saunders et al., 2016). Non-probability sampling is deemed more fitting when the purpose is to test the proposed theoretical assumptions (Hulland et al., 2018). With the amount of effort dedicated to investigating and understanding human behaviour, which itself is complex, it is of no surprise that the methodological development in business research is occurring more rapidly than ever (Memon et al., 2017). The sample unit is life insurance policyholders in Sri Lanka, and a sample of 100 life insurance policyholders was selected systematically to represent the population of the study. 


\subsection{Scale Construction and Evaluation}

The scale construction and evaluation process consisted of several procedural steps.

\section{Phase 1}

The first step involved a substantial review of extant literature that covered the related theories and existing measures. Schema theory was found to be useful to explain the linkage between consumer intrinsic value, brand trust and consumer-brand related behavior within the life insurance context. Several existing scales were also identified during this stage.

\section{Phase 2}

A pool of items was generated to measure the constructs in the second step. Existing scales and measures were thoroughly reviewed, and new items were developed to improve the face validity. A total of 24 items were developed to measure the constructs.

\section{Phase 3}

A panel of experts reviewed the initial item pool to assess content validity and ensure content adequacy of the scale items (DeVellis, 2017). The item pool comprising 24 items was reviewed by academic experts and insurance industry practitioners. These expert reviewers advised to rewrite some of the items and select the final list of items relying on the content, clarity, conciseness, and relevance criteria. This did not result in the reduction of the measures in the developed scale. 16 items in the scale were measured on a 5-point Likert scale, and another 8 items were measured on a 7-point Likert scale. Finally, questionnaires were distributed among the selected sample to evaluate the reliability and validity of the scale.

\subsection{Measurement of Variables}

The construct, consumer-brand relationship behaviour was operationalized and measured using a fivepoint Likert scale. The latent constructs hedonic value (Kim et al., 2020; Blinda et al., 2019; Morgan and Hunt, 1994; Dastan and Gecti, 2014), altruistic value (Gallarza et al., 2017; Dastan and Gecti, 2014; Prakash et al., 2003; Holbrook 2006) and brand trust (Chaudhuri and Holbrook, 2002; Delgado et al., 2003; Arnott et al., 2007; Kuikka and Laukkanen, 2012) were operationalized and measured using seven-point Likert scale. Operationalization of the latent constructs is shown in Table I. 
Table I: Operationalization of Constructs

\begin{tabular}{|c|c|c|}
\hline \multicolumn{3}{|l|}{ Hedonic value } \\
\hline Exciting new Services & $\begin{array}{l}\text { Voss et al. 2003; Wakefield and Baker 1998; Arnold and Reynolds } \\
\text { 2003; Deb } 2012\end{array}$ & HV1 \\
\hline Refresh their mood & Voss et al. 2003; Wakefield and Baker 1998 & HV2 \\
\hline Stimulation & Westbrook and Black 1985; Khare 2011; Voss et al. 2003 & HV3 \\
\hline Escape & Wakefield and Baker 1998; Voss et al. 2003 & HV4 \\
\hline Demand for services & Yavas 2003; Voss et al. 2003 & HV5 \\
\hline $\begin{array}{l}\text { Excellent customer } \\
\text { services }\end{array}$ & Kyle et al. 2004; Alexandris et al. 2006; Voss et al. 2003 & HV6 \\
\hline Self-esteem of customer & Holbrook 1999; Chandon et al. 2000; Voss et al. 2003 & HV7 \\
\hline \multicolumn{3}{|l|}{ Altruistic value } \\
\hline Positive feeling and & Hirschman \& Holbrook 1982; Voss et al. 2003 & HV8 \\
\hline Value alignment & Holbrook 1999 & AV2 \\
\hline Faith & Holbrook 1999 & AV3 \\
\hline Sacredness & Holbrook 1999 & AV4 \\
\hline \multicolumn{3}{|l|}{ Brand trust } \\
\hline Rely & Becerra and Badrinarayanan 2013; Delgado et al. 2003 & BT1 \\
\hline Trustworthy & Becerra and Badrinarayanan 2013; Delgado et al. 2003 & BT2 \\
\hline Safe & Becerra and Badrinarayanan 2013; Delgado et al. 2003 & BT3 \\
\hline Honest & Becerra and Badrinarayanan 2013; Delgado et al. 2003 & BT4 \\
\hline \multicolumn{3}{|c|}{ Consumer-brand relationship } \\
\hline Informed & Veloutsou 2015; Fetscherin and Heinrich 2015 & CBR1 \\
\hline Learn & Veloutsou 2015 & CBR2 \\
\hline Interest & Veloutsou 2015 & CBR3 \\
\hline Give feedback & Veloutsou 2015 & CBR4 \\
\hline Care & Veloutsou 2015; Fetscherin and Heinrich 2015 & CBR5 \\
\hline Close & Veloutsou 2015 & CBR6 \\
\hline Benefit & Veloutsou 2015 & CBR7 \\
\hline More important & Veloutsou 2015 & CBR8 \\
\hline
\end{tabular}

\subsection{Method Bias}

Many authors believed that method bias is a problem that needs to be addressed (Podsakoff et al., 2012). There may be a tendency to acquiesce to extremely worded items in a questionnaire. It has been suggested that abstract questions are a more difficult task than answering specific and straightforward questions. Therefore, to minimize this bias, the researchers created simple questions. A latent construct capturing systematic variance among its measures is considered method bias. It is a problem that may lead to erroneous perceptions about the level of scale's reliability and convergent validity. Appropriate remedies were used to minimize any impact from method bias, even after implementing the procedural method of control. 


\section{ANALYSIS}

Kaiser Meyer Olkin (KMO) and Bartlett's test was examined to determine whether the data is appropriate for exploratory factor analysis. Adequacy level of the sample was measured using the KMO test, and the value of KMO test was 0.856 . The result of this KMO value is more significant than 0.6, and this level is useful for factor analysis (Hair et al. 2006). According to the KMO test, these selected sample data suitable for factor analysis with Bartlett's test of sphericity value to be 2619.386 at a level of significance $\mathrm{p}=0.000$.

\subsection{Factor Extraction}

The factor extraction resulted in the higher communalities greater than 0.6 , and they can be considered better (Hair et al., 2006; MacCallum et al., 2001). Communalities lower than 0.4 may be problematic (Comrey and Lee, 1992). Communalities value of all the items is presented in Table II.

\section{Table II: Communalities of factors}

\begin{tabular}{|c|c|}
\hline \multicolumn{2}{|l|}{ Hedonic value } \\
\hline HV1 I enjoy being immersed in exciting new types of life insurance policies & 0.803 \\
\hline $\begin{array}{l}\text { HV2 Inclusion of recreational programs in insurance policy makes me relaxed from the stressful life } \\
\text { style }\end{array}$ & 0.797 \\
\hline $\begin{array}{l}\text { HV3 The continuity of insurance policy gives me a possibility of resolving my future problems in a } \\
\text { stimulating manner }\end{array}$ & 0.729 \\
\hline HV4 My life insurance policy truly feels like an escape from my future problems & 0.706 \\
\hline HV5 At present, a high demand exists for life insurance services & 0.635 \\
\hline HV6 An excellent customer service from insurance sales persons create loyalty & 0.933 \\
\hline HV7 Being a life insurance policy holder gains me higher social status and increase self- esteem & 0.677 \\
\hline $\begin{array}{l}\text { HV8 The positive environment of life insurance company creates a positive feeling and confidence } \\
\text { in my life }\end{array}$ & 0.915 \\
\hline \multicolumn{2}{|l|}{ Altruistic value } \\
\hline AV1 I purchase a life insurance to avoid myself being a responsibility to others & 0.839 \\
\hline AV2 I like to give something to the society through (CSR) my insurance company & 0.871 \\
\hline AV3 I was to pass away early in life, my life insurance policy beneficial for my dependents & 0.839 \\
\hline AV4 I purchase my life insurance policy in order to take care of others & 0.889 \\
\hline \multicolumn{2}{|l|}{ Brand trust } \\
\hline BT1 I rely on my preferred insurance brand & 0.713 \\
\hline BT2 My preferred insurance brand is trustworthy & 0.657 \\
\hline BT3 My preferred insurance brand is safe & 0.667 \\
\hline BT4 My preferred insurance brand is honest & 0.827 \\
\hline \multicolumn{2}{|l|}{ Consumer-brand Relationship Behaviour } \\
\hline CBR1 I want to be informed about my preferred brand of insurance & 0.742 \\
\hline
\end{tabular}




\begin{tabular}{|l|c|}
\hline CBR2 I am more willing to learn news about my preferred brand of insurance than for other Brands & 0.877 \\
\hline CBR3 I listen to information about my favorite brand of insurance with interest & 0.738 \\
\hline CBR4 I am willing to give feedback to the service provider of my preferred brand of insurance & 0.699 \\
\hline CBR5 I care about the developments relevant to my preferred brand of insurance & 0.866 \\
\hline CBR6 My preferred brand of insurance is like a person with whom I am close & 0.886 \\
\hline CBR7 Both my preferred brand of insurance and I benefit from our link & 0.814 \\
\hline CBR8 Over the time, my preferred brand of insurance becomes more important to me & 0.829 \\
\hline
\end{tabular}

The initial number of factors is the same as the number of variables used in the factor analysis. Table III presents a total column containing the eigenvalues and variance column includes each total factor variance as a percentage. Cumulative percentage of the column's fourth row shows a value of 78.95. This means four factors account for $79 \%$ of the total variance.

Table III: Variance Extracted by factor solution

\begin{tabular}{ccccccc}
\hline & \multicolumn{3}{c}{ Initial Eigenvalues } & \multicolumn{2}{c}{ Rotation Sums of Squared Loadings } \\
\hline Component & Total & $\begin{array}{c}\text { \% of } \\
\text { Variance }\end{array}$ & $\begin{array}{c}\text { Cumulative } \\
\%\end{array}$ & Total & $\begin{array}{c}\text { \% of } \\
\text { variance }\end{array}$ & $\begin{array}{c}\text { Cumulative } \\
\%\end{array}$ \\
\hline 1 & 9.21 & 38.375 & 38.375 & 6.455 & 26.894 & 26.894 \\
2 & 4.371 & 18.212 & 56.587 & 6.168 & 25.700 & 52.595 \\
3 & 3.216 & 13.398 & 69.985 & 3.503 & 14.598 & 67.192 \\
4 & 2.151 & 8.964 & 78.95 & 2.822 & 11.757 & 78.95 \\
\hline
\end{tabular}

The scree plot graphs the eigenvalue against the factor number. Eigenvalues are shown in the first four columns of Table III. The line in the scree plot is almost flat beyond the fourth factor. The Elbow shape scree plot is shown in Figure I.

Figure 1: Scree plot: Eigen values for factor

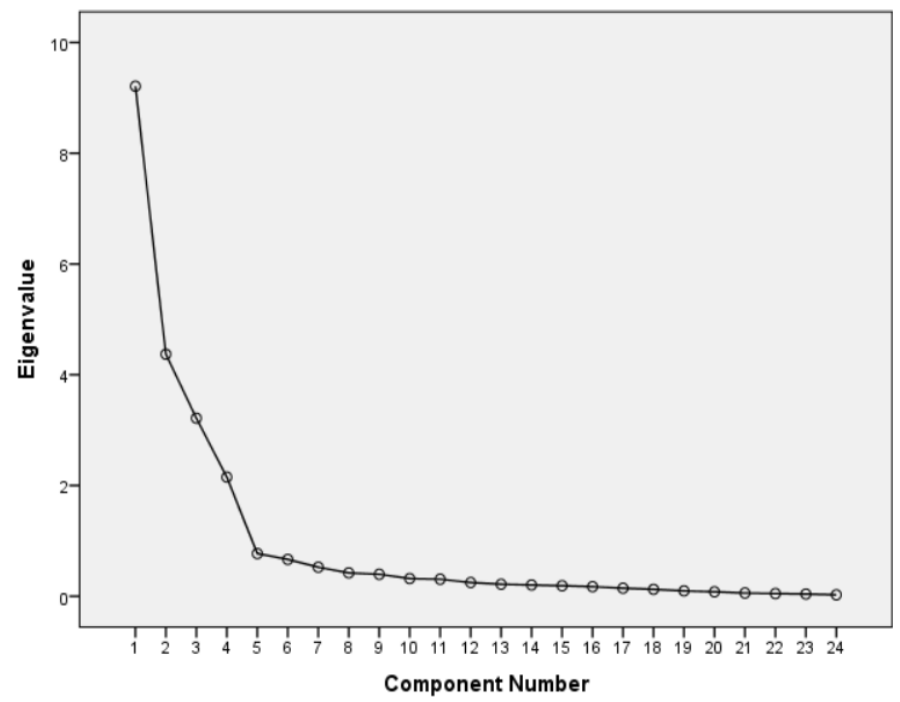




\subsection{Factor Rotation}

The rotated component matrix is indicated in Table IV below. The factor extracts are associated, and there should be some separation among the variables. This rotated component matrix is a matrix of the factor loading for each variable on to each factor; it has interpreted these results and duly assigned the following labels. Factor 1 was named as the consumer-brand relationship, which was measured using eight items. Factor 2 represent the hedonic value, and this factor comprises eight items. Altruistic value and brand trust have been represented by factor 3 and factor 4 .

Table IV: Rotated Component Matrix

\begin{tabular}{|c|c|c|c|c|}
\hline Items & Factor 1 & Factor 2 & Factor 3 & Factor 4 \\
\hline CBR5 & 0.923 & & & \\
\hline CBR8 & 0.905 & & & \\
\hline CBR6 & 0.888 & & & \\
\hline CBR7 & 0.881 & & & \\
\hline CBR2 & 0.858 & & & \\
\hline CBR1 & 0.847 & & & \\
\hline CBR3 & 0.844 & & & \\
\hline CBR4 & 0.811 & & & \\
\hline HV8 & & 0.927 & & \\
\hline HV6 & & 0.916 & & \\
\hline HV1 & & 0.884 & & \\
\hline HV2 & & 0.874 & & \\
\hline HV3 & & 0.842 & & \\
\hline HV7 & & 0.82 & & \\
\hline HV4 & & 0.809 & & \\
\hline HV5 & & 0.754 & & \\
\hline AV2 & & & 0.902 & \\
\hline AV4 & & & 0.893 & \\
\hline AV1 & & & 0.891 & \\
\hline AV3 & & & 0.883 & \\
\hline BT4 & & & & 0.862 \\
\hline BT1 & & & & 0.831 \\
\hline BT3 & & & & 0.803 \\
\hline BT2 & & & & 0.779 \\
\hline
\end{tabular}




\subsection{Reliability and Validity}

Several tools to measure reliability and validity was applied. Reliability refers to the consistency of measurements when the testing procedure is repeated on a population of individuals or groups. Cronbach's alpha values indicate the internal consistency of the item. Reliability level can be measured using Cronbach's alpha, and the rule of thumb is greater than 0.9 to be excellent, 0.9 to 0.8 as good, 0.8 to 0.7 to be acceptable, 0.7 to 0.6 as questionable, 0.6 to 0.5 to be poor and less than 0.5 is considered unacceptable (George, 2011). The reliability analysis revealed that the alpha coefficient of the four constructs as 0.953 for hedonic value, 0.946 for altruistic value, 0.850 for brand trust and 0.961 for consumer-brand relationship.

Table V: Reliability Testing on Cronbach's Alpha Values

\begin{tabular}{lcc}
\hline \multicolumn{1}{c}{ Constructs } & Number of items & Cronbach's Alpha values \\
\hline Hedonic value & 8 & 0.953 \\
Altruistic value & 4 & 0.946 \\
Brand trust & 4 & 0.850 \\
Consumer-brand relationship & 8 & 0.961 \\
\hline
\end{tabular}

As suggested by Fornell and Larcker (1981), the measurement model's convergent validity can be assessed by the composite reliability (CR) and average variance extracted (AVE). Convergent validity measures the extent to which factors that ought to measure a single construct agree with each other. In this study, convergent validity was assessed using the average variance explained and composite reliability. Composite reliability should be greater than 0.6 and AVE should be above 0.5 for all constructs (Ode and Ayavoo, 2020). As shown in Table VI, composite reliability ranges from 0.848 to 0.962 while the average variance extracted range from 0.589 to 0.815 . These results show that the model meets the criteria for convergent validity.

Discriminant validity of the constructs was measured by comparing the square root of average variance extracted with the inter-construct correlation. The results are presented in Table VI. As the square root of AVE of each construct is higher than its correlations with the rest of the constructs giving evidence of discriminant validity. The diagonal elements (*) shown in Table VI are the squared multiple correlations between the constructs. Further, Table VI also presents the AVE ranges from 0.589 to 0.815 while the diagonal values range from 0.768 to 0.903 , indicating that the diagonal variables are higher than the various AVE values suggesting that all the constructs in this study have adequate discriminant validity. In testing for evidence of discriminant validity, it is expected that the squared roots of AVE values to be greater than the corresponding inter-construct correlations and AVE to exceed the Maximum Shared Variance (MSV) (Ode and Ayavoo 2020).

Table VI: Reliability, Validity and Correlations 


\begin{tabular}{lcccccccc}
\hline Construct & CR & AVE & MSV & MaxR(H) & BT & HV & AV & CBR \\
\hline BT & 0.848 & 0.589 & 0.108 & 0.922 & $0.768^{*}$ & & & \\
HV & 0.954 & 0.722 & 0.147 & 0.975 & 0.196 & $0.849 *$ & & \\
AV & 0.946 & 0.815 & 0.135 & 0.951 & 0.328 & 0.317 & $0.903^{*}$ & \\
CBR & 0.962 & 0.762 & 0.147 & 0.967 & 0.284 & 0.383 & 0.367 & $0.873^{*}$
\end{tabular}

Notes: $\mathrm{CR}=$ composite reliability; $\mathrm{AVE}=$ average variance extracted $\mathrm{MSV}=$ maximum shared variance; $\operatorname{MaxR}(\mathrm{H})=$ maximum reliability; $(\mathrm{H})$ and $*=$ square root of AVE.

\section{DISCUSSION AND CONCLUSION}

This study used survey data and exploratory factor analysis technique to develop and validate a scale to measure hedonic value, altruistic value, brand trust and consumer-brand relationship for the life insurance industry in Sri Lanka. The contribution of this study depends on the examination of these four sets of factors and empirical investigation based on principle component analysis technique. This study has attempted to measure hedonic value, altruistic value, brand trust and the consumer-brand relationship of the life insurance sector. It was proved that continuous analysis of these four factors would provide sufficient information. The findings confirm that consumer intrinsic value is the result of a dynamic interaction among a few complex, integrated emotional dimensions which jointly form the consumer-brand relationship. These scale development and validation are relevant for both scholars and insurance practitioners working on consumer-brand relationship understanding and management. The three constructs, such as hedonic value, altruistic value and brand trust, were positively related to consumer-brand relationship. This study has illustrated how the commonly used to scale development process can be adapted to develop a scale for a new construct in the life insurance context. As the scales provide empirical evidence on reliability, convergent validity and discriminant validity, these scales will be useful in many research contexts and facilitate useful academic and managerial driven research.

This study found that life insurance industry significantly depends on brand trust. Therefore, management should make decision considering brand trust. Further, firms should create intrinsic benefit with existing customer and it should properly communicate with customer. In particularly, life insurance firms should give more attention to customer learning. The scale proposed in this paper provides an efficient way for insurance and similar service providers to measure customer values, brand trust, and consumer-brand relationship to cater to their respective organizations. Further, the scale could provide evidence whether how consumer values, brand trust and consumer-brand relationship is viewed by consumers belonging to different strata of the society. In sum, this shall guide insurance and similar service providers to embed learning from using this scale to improve product features, corporate communications, and consumer engagement. 


\section{LIMITATIONS AND FUTURE RESEARCH}

Similar to other studies available in the literature, this study too carries certain limitations, and subsequently provide opportunities for future research. This study was conducted mainly based on Schema theory on the life insurance industry in Sri Lanka. The schema theory can be discussed at various angles. Although the results are robust, future work could incorporate larger sample data. This study is conducted using consumer-brand relationship behavior in the insurance industry, and it does not involve others in general. Therefore, the result may not be generalizable. Thus, the researcher proposes to extend future studies on different market-based applications. Customers nowadays are more knowledgeable, and they are always connected through digital media. Therefore, the insurance sector needs to be more advanced, scientific and excel in technological knowledge.

\section{REFERENCES}

Alexandris, K., Kouthouris, C., Andreas, Meligdis, (2006). Increasing customers' loyalty in a skiing resort. International Journal of Contemporary Hospitality Management 18 (5), 414.

Arnold, M. J., \& Reynolds, K. E. (2003). Hedonic shopping motivations. Journal of Retailing, 79(2), 77-95.

Becerra, E., \& Badrinarayanan, V. (2013). The influence of brand trust and brand identification on brand evangelism. Journal of Product \& Brand Management, 22(5/6), 371-383.

Blackston, M., \& Lebar, E. (2015). Constructing consumer-brand relationships to better market and build businesses. Fournier, S., Breazeale, M., Avery, J., editors. Strong Brands, Strong Relationships. Abingdon, Oxon: Routledge, p376.

Blinda, K., Schnittka, O., Sattler, H., \& Gräve, J. F. (2019). Implementing effective customer participation for hedonic and utilitarian services. Journal of Services Marketing, 33(3), 316-330.

Chaudhuri, A., \& Holbrook, M. B. (2002). Product-class effects on brand commitment and brand outcomes: The role of brand trust and brand affect. Journal of Brand Management, 10(1), 33-58.

Chandon, P., Wansink, B., \& Laurent, G. (2000). A benefit congruency framework of sales promotion effectiveness. Journal of Marketing, 64(4), 65-81.

Comrey, A., \& Lee, H. (1992). A First Course in Factor Analysis.2nd ed. Lawrence Earlbaum Associates. Publishers: Hillsdale, New Jersey.

Creyer, E. H. (1997). The influence of firm behavior on purchase intention: do consumers really care about business ethics. Journal of consumer Marketing, 14(6), 421-432.

Dastan, I., \& Gecti, F. (2014). Relationships among utilitarian and hedonic values, brand affect and brand trust in the smartphone industry. Journal of Management Research, 6(2), 124.

DeVellis, R. F. (2016). Scale development: Theory and applications (Vol. 26). Sage publications. P 152

Davvetas, V. \& Halkias, G. (2019). "Global and local brand stereotypes: formation, content transfer, and impact", International Marketing Review, 36(5), 675-701

Davvetas, V., \& Diamantopoulos, A. (2018). "Should have I Bought the other One” Experiencing Regret in Global versus Local Brand Purchase Decisions. Journal of International Marketing, 26(2), 1-21. 
Davvetas, V., \& Diamantopoulos, A. (2016). How product category shapes preferences toward global and local brands: a schema theory perspective. Journal of International Marketing, 24(4), 61-81.

Deb, M.,2012. Evaluation of customer's mall preferences in India using fuzzy AHP approach. Journal of Advances in Management Research.9(1),29-44.

Delgado-Ballester, E., Munuera-Aleman, J. L., \& Yague-Guillen, M. J. (2003). Development and validation of a brand trust scale. International Journal of Market Research, 45(1), 35-54.

Delport, H., Steyn, T. F. J., \& Mostert, P. G. (2011). Relationship intention of South African banking and life insurance customers. Journal of Financial Services Marketing, 16(3-4), 277-293.

Desai, K. K., \& Raju, S. (2007). Adverse influence of brand commitment on consideration of and preference for competing brands. Psychology \& Marketing, 24(7), 595-614.

Elliott, R., \& Yannopoulou, N. (2007). The nature of trust in brands: a psychosocial model. European Journal of Marketing, 41(9/10), 988-998.

Evely, A., Fazey, I., Pinard, M., \& Lambin, X. (2008). The influence of philosophical perspectives in integrative research: a conservation case study in the Cairngorms National Park. Ecology and Society, 13(2).52-68

Fetscherin, M., \& Heinrich, D. (2015). Consumer brand relationships research: A bibliometric citation metaanalysis. Journal of Business Research, 68(2), 380-390.

Fornell, C., \& Larcker, D. F. (1981). Evaluating structural equation models with unobservable variables and measurement error. Journal of marketing research, 18(1), 39-50.

Fournier, S. (1998). Consumers and their brands: Developing relationship theory in consumer research. Journal of Consumer Research, 24(4), 343-373.

Frondizi, R. (1971), What Is Value, An Introduction to Axiology, 2nd ed., Open Court, La Salle, IL.

Gallarza, M. G., Arteaga-Moreno, F., Del Chiappa, G., \& Gil-Saura, I. (2016). Intrinsic value dimensions and the value-satisfaction-loyalty chain: a causal model for services. Journal of Services Marketing, 30(2), 165-185.

Gallarza, M. G., Arteaga, F., Del Chiappa, G., Gil-Saura, I., \& Holbrook, M. B. (2017). A multidimensional servicevalue scale based on Holbrook's typology of customer value. Journal of Service Management, 28(4), 724-762.

George, D. (2011). SPSS for windows step by step: A simple study guide and reference, 17.0 update, 10/e. Pearson Education India.

Ghani, N. H. A., \& Tuhin, K. W. (2018). Evolution of Consumer Brand Relationship Research. Academy of Strategic Management Journal.17(1),1-7

Gunawardane, N., Munasinghe, A., \& Dissanayake, D. M. R. (2016). Relationship between Perceived Brand Equity and Purchase Intention of Life Insurance Brands in Sri Lanka: A Concept Paper. International Journal of Business and Management Invention, 5(12),106-111

Hair, J. F., Black, W. C., Babin, B. J., Anderson, R. E., \& Tatham, R. L. (2006). Multivariate data analysis 6th Edition. Pearson Prentice Hall. New Jersey. humans: Critique and reformulation. Journal of Abnormal Psychology, 87, 49-74.

Halkias, G., \& Kokkinaki, F. (2017). Schema strength, processing opportunity, and the rewarding nature of incongruity resolution in advertising. International Journal of Advertising, 36(3), 415-438.

Halkias, G. (2015). Mental representation of brands: a schema-based approach to consumers' organization of market knowledge. Journal of Product \& Brand Management, 24(5), 438-448.

Hess, J., \& Story, J. (2005). Trust-based commitment: multidimensional consumer-brand relationships. Journal of Consumer Marketing, 22(6), 313-322. 
Hirschman, E. C., \& Holbrook, M. B. (1982). Hedonic consumption: emerging concepts, methods and propositions. The Journal of Marketing, 92-101.

Holbrook, M. B. (1999). Consumer value: A Framework for Analysis and Research; Routledge: London, UK.

Holbrook, M. B. (2006). Consumption experience, customer value, and subjective personal introspection: An illustrative photographic essay. Journal of business research, 59(6), 714-725.

Hulland, J., Baumgartner, H., \& Smith, K. M. (2018). Marketing survey research best practices: evidence and recommendations from a review of JAMS articles. Journal of the Academy of Marketing Science, 46(1), 92-108.

IBSL. Annual Report 2016; Insurance Board of Sri Lanka: Colombo, Sri Lanka

Keller, K. L. (2012). Understanding the richness of brand relationships: Research dialogue on brands as intentional agents. Journal of Consumer Psychology, 22(2), 186-190.

Khare, A., \& Rakesh, S. (2011). Retailing in Indian malls: Antecedents to retailers' preferences for mall-store space. The International Review of Retail, Distribution and Consumer Research, 21(2), 187-200.

Kim, K., Choi, H. J., \& Hyun, S. S. (2020). Coffee House Consumers' Value Perception and Its Consequences: MultiDimensional Approach. Sustainability, 12(4), 1663.

Kim, M. Y., Moon, S., \& Iacobucci, D. (2019). The Influence of Global Brand Distribution on Brand Popularity on Social Media. Journal of International Marketing, 27(4), 22-38.

Kuikka, A., \& Laukkanen, T. (2012). Brand loyalty and the role of hedonic value. Journal of Product \& Brand Management, 21(7), 529-537.

Kyle, G., Graefe, A., Manning, R., \& Bacon, J., 2004. Predictors of behavioral loyalty among hikers along the Appalachian Trail. Leisure Sciences 26 (1), 99-118.

Louis, D., \& Lombart, C. (2010). Impact of brand personality on three major relational consequences (trust, attachment, and commitment to the brand). Journal of Product \& Brand Management, 19(2), 114-130.

MacCallum, Robert C., Keith F. Widaman, Kristopher J. Preacher, \& Sehee Hong., (2001) Sample size in factor analysis: The role of model error. Multivariate Behavioral Research 36(4), 611-637.

MacInnis, D. J., \& Folkes, V. S. (2017). Humanizing brands: When brands seem to be like me, part of me, and in a relationship with me. Journal of Consumer Psychology, 27(3), 355-374.

Mason, T. (2000). The importance of being ethical. Marketing, 26(10), 1-27.

Memon, M. A., Ting, H., Ramayah, T., Chuah, F., \& Cheah, J. H. (2017). A review of the methodological misconceptions and guidelines related to the application of structural equation modeling: A Malaysian scenario. Journal of applied structural equation modeling, 1(1), 1-13.

Morgan, R. M., \& Hunt, S. D. (1994). The commitment-trust theory of relationship marketing. Journal of marketing, 58(3), 20-38.

Morris B. Holbrook (1996), Special Session Summary Customer Value C a Framework for Analysis and Research, Advances in Consumer Research, Volume 23, 138-142.

Nunnally, J. C., \& Bernstein, I. H. (1967). McGraw-Hill series in psychology. Psychometric theory. New York, NY, US: McGraw-Hill.

Ode, E., \& Ayavoo, R. (2020). The mediating role of knowledge application in the relationship between knowledge management practices and firm innovation. Journal of Innovation \& Knowledge, 5(3), 210-218.

Oliver, R. L. (1999). Whence consumer loyalty, Journal of marketing, 63(4), 33-44.

Perry, R. B. (1954). Realms of Value, A Critique of the Theory of a Political Concept. 
Podsakoff, P. M., MacKenzie, S. B., \& Podsakoff, N. P. (2012). Sources of method bias in social science research and recommendations on how to control it. Annual review of psychology, 63, 539-569.

Prakash, G., Choudhary, S., Kumar, A., Garza-Reyes, J. A., Khan, S. A. R., \& Panda, T. K. (2019). Do altruistic and egoistic values influence consumers' attitudes and purchase intentions towards eco-friendly packaged products? An empirical investigation. Journal of Retailing and Consumer Services, 50, 163-169.

Rahmawati, H. (2018). Do Brand Credibility and Altruistic Attribution Affect Corporate Philanthropy Performance, The Moderating Effect of Gen Y's Hedonic Behavior, international journal of business and society, 19 (1), 27-40

Robson, J. (2015). General insurance marketing: A review and future research agenda. Journal of Financial Services Marketing, 20(4), 282-291.

Saunders, M., Lewis, P., \& Thornhill, A. (2016). Research Methods for Business Students (7th ed.). Essex, England: Pearson Education Limited.

Schwartz, S. H. (1994). Are there universal aspects in the structure and contents of human values, Journal of Social Issues, 50(4), 19-45

Sekhon, H., \& Kennington, C. (2001). Buyer seller relationships in the UK insurance market: Is this the key competitive advantage. Journal of Financial Services Marketing, 5(3), 207-214.

Steg, L., Perlaviciute, G., Van der Werff, E., \& Lurvink, J. (2014). The significance of hedonic values for environmentally relevant attitudes, preferences, and actions. Environment and behavior, 46(2), 163-192.

Sheth, J. N., \& Parvatiyar, A. (1995). Relationship marketing in consumer markets: antecedents and consequences. Journal of the Academy of Marketing Science, 23(4), 255-271.

Tiefenbacher, K., \& Olbrich, S. (2015). Increasing the Level of Customer Orientation-A Big Data Case Study from Insurance Industry. In ECIS.

United Nations, (2017). Department of Economic and Social Affairs, Population Division. World Population Ageing.

Veloutsou, C. (2015). Brand evaluation, satisfaction and trust as predictors of brand loyalty: the mediator-moderator effect of brand relationships. Journal of Consumer Marketing, 32(6), 405-421.

Voss, K. E., Spangenberg, E. R., \& Grohmann, B. (2003). Measuring the hedonic and utilitarian dimensions of consumer attitude. Journal of Marketing Research, 40(3), 310-320.

Wakefield, K. L., \& Baker, J. (1998). Excitement at the mall: determinants and effects on shopping response. Journal of retailing, 74(4), 515-539.

Westbrook, R. A., \& Black, W. C. (1985). A motivation-based shopper typology. Journal of retailing, 61(1), 78-103.

Yavas, U. (2003). A multi-attribute approach to understanding shopper segments. International Journal of Retail \& Distribution Management, 31(11), 541-548. 